\title{
PERBANDINGAN KADAR GULA DARAH POST-PRANDIAL PADA WANITA OBES SENTRAL DENGAN DAN TANPA RIWAYAT KELUARGA PENYAKIT KARDIOVASKULAR
}

\author{
${ }^{1}$ Arum P. S. Widyaningrum \\ ${ }^{2}$ Sunny Wangko \\ ${ }^{2}$ George N. Tanudjaja
}

\author{
${ }^{1}$ Kandidat Skripsi Fakultas Kedokteran Universitas Sam Ratulangi Manado \\ ${ }^{2}$ Bagian Anatomi Histologi Fakultas Kedokteran Universitas Sam Ratulangi Manado \\ Email: arum.purnama@yahoo.com
}

\begin{abstract}
Inflammatory process plays some important roles in the occurence of insulin resistance in obesity which inhibits the glucose molecules from entering the cells. In obesity, adipocytes produce active biological molecules called adipokines, some of which worsen the inflammatory process. Insulin resistance results in increases of fasting and post-prandial blood glucose. This study aimed to determine the comparison of post-prandial glucose in central obese women with and without family histories of cardiovascular diseases. This was a cross sectional design study, using a purposive sampling method. This study was carried out at Kairagi Weru Lingkungan IV, Manado.There were 44 respondents that met the inclusion criteria. The data used were BMI, waist circumference, questionnaires, and 2-hour-postprandial blood glucose examinations. The results showed that most of the respondents were 46-50 years old. For all respondents, there was no significant correlation $(P>0.05)$ between ages and post-prandial blood glucose levels, or between the BMIs and post-prandial blood glucose levels. The statistic analysis showed that there was no correlation $(P=0.680)$ between cardiovascular disease family histories and post-prandial blood glucose levels. Besides that, there was no significant difference $(P=0.209)$ between post-prandial blood glucose levels among samples with or without cardiovascular disease family histories. Conclusion: There was no significant difference in the 2-hour-post-prandial blood glucose levels among the central obese women with or without family histories of cardiovascular diseases.
\end{abstract}

Keywords: cardiovascular disease, central obesity, family history, postprandial.

\begin{abstract}
Abstrak: Reaksi inflamasi berperan dalam resistensi insulin pada obesitas yang mengakibatkan glukosa sulit memasuki sel. Pada obesitas, adiposit menghasilkan molekul biologis aktif, yaitu adipokin; beberapa di antaranya memperburuk proses inflamasi. Resistensi insulin menghasilkan peningkatan kadar gula darah puasa dan post-prandial. Penelitian ini bertujuan untuk mengetahui perbandingan kadar gula darah dua jam postprandial pada wanita obes sentral dengan atau tanpa riwayat keluarga penyakit kardiovaskular. Penelitian ini menggunakan desain cross sectional dan dilakukan di Kelurahan Kairagi Weru Lingkungan IV pada bulan Oktober-November 2012. Sampel sebanyak 44 orang, yang didapatkan dengan menggunakan teknik purposive sampling. Data diperoleh melalui pemeriksaan IMT dan LP, pengisian kuesioner, serta pemeriksaan kadar gula darah dua jam post-prandial. Hasil penelitian memperlihatkan bahwa sebagian besar sampel berusia 46-50 tahun. Analisis statistik menunjukkan untuk semua sampel tidak terdapat korelasi bermakna $(P>0,05)$ antara usia dan kadar gula darah post-prandial, atau antara IMT dan kadar gula darah post-prandial. Tidak terdapat korelasi $(P=0,680)$ antara sampel yang dengan atau tanpa riwayat keluarga penyakit kardiovaskular dan kadar gula
\end{abstract}


darah post-prandial. Selain itu, tidak terdapat perbedaan bermakna $(P=0,209)$ antara kadar gula darah post-prandial blood glucose levels pada sampel dengan dan tanpa riwayat keluarga penyakit kardiovaskular. Simpulan: Tidak terdapat perbedaan bermakna antara kadar gula darah dua jam postprandial pada wanita obes sentral dengan dan tanpa riwayat keluarga penyakit kardiovaskular.

Kata kunci: obes sentral, postprandial, penyakit kardiovaskular, riwayat keluarga.

Obesitas merupakan penyakit multifaktorial yang telah menjadi masalah kesehatan global dunia. ${ }^{1,2}$ Obesitas didefinisikan sebagai suatu kondisi dengan akumulasi lemak abnormal atau berlebihan dalam jaringan adiposa. $^{3}$ Menurut WHO, diperkirakan sekitar 2,3 miliar individu obes berusia 15 tahun ke atas dan lebih dari 700 juta penduduk di seluruh dunia menyandang obesitas pada tahun 2015 . $^{2} \mathrm{Di}$ Indonesia, angka kejadian obesitas tahun 2002 diperkirakan sekitar 48-53 juta penduduk. ${ }^{4}$ Tahun 2010 angka kejadian obesitas di atas usia 18 tahun untuk pria $7,8 \%$ dan wanita $15,5 \%$. Angka kejadian obesitas di Sulawesi Utara untuk pria $14,3 \%$ dan wanita 29,5\%..$^{5}$ The National Health and Nutrition Examination Survey III (NHANES III) 1988-1994 menunjukkan bahwa $20 \%$ pria dewasa dan $25 \%$ wanita dewasa Amerika mempunyai indeks massa tubuh (IMT) melebihi $30,00 \mathrm{~kg} / \mathrm{m}^{2}$, sedangkan sepertiga lainnya mempunyai IMT $25,00-30,00 \mathrm{~kg} / \mathrm{m}^{2}$.

Pada individu dengan metabolisme normal, insulin dilepaskan dari sel B pulau Langerhans pankreas setelah makan (postprandial) yang kemudian mengirim sinyal ke jaringan yang sensitif insulin untuk menyerap glukosa. Sel-sel $\beta$ akan mengurangi output insulin saat kadar glukosa turun. ${ }^{7}$

Zhen-Zhong et al. ${ }^{8}$ menyatakan bahwa reaksi inflamasi berperan dalam menimbulkan resistensi insulin pada obesitas. Insulin berperan penting baik pada penyimpanan maupun sintesis lemak dalam jaringan adiposa. Resistensi insulin dapat menyebabkan terganggunya proses penyimpanan lemak maupun sintesis lemak. ${ }^{9}$ Hal ini menimbulkan penurunan aksi insulin sehingga glukosa sulit memasuki sel yang berakibat terjadi peningkatan kadar glukosa dalam darah. ${ }^{8}$ Semakin tingginya resistensi insulin dapat terlihat pada peningkatan kadar gula darah puasa dan postprandial. $^{9}$ Peningkatan kadar gula darah disertai dengan penurunan aksi insulin akan mencetuskan terjadinya gangguan metabolisme berupa diabetes melitus (DM). ${ }^{8}$

Beberapa mekanisme seperti dislipidemia, obesitas, stres oksidatif, merokok, konsumsi alcohol, dan faktor-faktor genetik tertentu telah diidentifikasi sebagai faktor risiko diabetes melitus tipe 2 (DMT2) dan penyakit arteri koronaria. Kurangnya gen polimorfisme apoliprotein E (Apo E) telah jelas sebagai penyebab utama hiperlipidemia dan perkembangan spontan arterosklerosis pada mamalia. Beberapa studi telah mampu menunjukkan hubungan antara DMT2 dan berbagai polimorfisme satu nukleotida. ${ }^{10}$

Pada tahun 2011, Ziljko et al. ${ }^{11}$ menyatakan bahwa gen polimorfisme Apo E ini juga terkait dengan obesitas dalam populasi di Kroasia Roma. Adiposit pada keadaan obesitas (yang merupakan komorbid DMT2) dapat menghasilkan sejumlah molekul biologis aktif yang disebut adipokin, antara lain plasminogen activator inhibitor-1 (PAI-1), resistin, leptin, interleukin-6 (IL-6), dan tumor necrosis factor alpha (TNF- $\alpha){ }^{11}$

Semua faktor-faktor tersebut di atas mendasari terjadinya sindrom metabolik. Pasien dengan sindrom metabolik memiliki risiko lebih tinggi terjadinya penyakit arteri koronaria dan lima kali lipat memiliki risiko terjadinya DMT2. Namun, individu yang menyandang DMT2 memiliki risiko tiga kali lipat terjadinya penyakit arteri koronaria. ${ }^{11}$ Dari uraian di atas, penulis tertarik untuk mengetahui perbandingan kadar gula darah post-prandial pada wanita obes sentral dengan dan tanpa riwayat 
keluarga penyakit kardiovaskular di Kelurahan Kairagi Weru Lingkungan IV.

\section{METODE PENELITIAN}

Penelitian ini dilakukan dengan metode analitik observasional dan desain studi cross sectional untuk membandingkan kadar gula darah postprandial pada wanita obes sentral dengan dan tanpa riwayat keluarga penyakit kardiovaskular. Penelitian dilakukan di Kelurahan Kairagi Weru Lingkungan IV pada bulan OktoberNovember 2012.

Populasi penelitian ialah wanita dengan obes sentral yang berdiam di Kelurahan Kairagi Weru Lingkungan IV, Manado. Sampel penelitian diambil dengan cara purposive sampling, yaitu wanita obes sentral yang memenuhi kriteria inklusi: usia 25-50 tahun, obesitas (IMT $\geq 25,0 \mathrm{~kg} / \mathrm{m}^{2}$ ), dan lingkat perut $\geq 80 \mathrm{~cm}$, dengan atau tanpa riwayat keluarga penyakit kardiovaskular, bersedia menjadi sampel penelitian, mengisi informed concent serta makan dua jam sebelum pengambilan darah. Sebagai kriteria ekslusi yaitu memiliki riwayat diabetes melitus dengan penggunaan obat anti diabetes, riwayat penyakit pada pankreas dan hati, riwayat gangguan hormonal, serta sedang hamil atau menstruasi.

Penghitungan indeks massa tubuh (IMT) dilakukan dengan rumus berat badan dibagi tinggi badan yang dikuadratkan $\left(\mathrm{BB} / \mathrm{TB}^{2}\right)$. Pengukuran lingkar perut menggunakan pita pengukur dan spidol, dengan menentukan titik tengah antara tepi tulang iga terbawah dan titik ujung krista iliaka, kemudian secara horizontal melingkari pinggang dan perut menuju titik tengah awal pengukuran. Pemeriksaan kadar gula darah dilakukan di Laboratorium Medistar Manado. Pengolahan data penelitian ini menggunakan uji non-parametrik Mann Whitney pada SPSS versi 20.

\section{HASIL PENELITIAN}

Penelitian dilakukan di Perumahan Gubernur Kelurahan Kairagi Weru
Lingkungan IV Kecamatan Paal Dua Kota Manado Provinsi Sulawesi Utara. Jumlah penduduk sebanyak 444 orang, terdiri dari 142 anak-anak dan 302 dewasa.

\section{Deskripsi karakteristik subjek penelitian}

Subjek penelitian ialah 44 wanita obes sentral yang tinggal di Kelurahan Kairagi Weru Lingkungan IV Manado dan memenuhi kriteria inklusi.

\section{Riwayat keluarga penyakit kardiovaskular}

Subjek penelitian ini terdiri dari 44 orang wanita obes sentral, yang dengan riwayat keluarga penyakit kardiovaskular $[\mathrm{RPK}(+)]$ dan yang tanpa riwayat penyakit kardiovaskular [RPK(-)] dalam jumlah yang sama besar (Tabel 1).

Tabel 1. Distribusi subjek penelitian berdasarkan dengan $[\mathrm{RPK}(+)]$ dan tanpa riwayat keluarga penyakit kardiovaskular [RPK(-)].

\begin{tabular}{ccc}
\hline Obes & Frekuensi & \% \\
\hline RPK (+) & 22 & 50 \\
RPK (-) & 22 & 50 \\
Total & 44 & 100 \\
\hline
\end{tabular}

\section{Usia}

Distribusi subjek penelitian dengan dan tanpa riwayat keluarga penyakit kardiovaskular yang sesuai dengan kriteria dalam penelitian berusia 26-50 tahun, terbanyak pada usia 46-50 tahun yaitu $27 \%$ untuk masing-masing kelompok (Tabel 2).

Tabel 2. Distribusi subjek penelitian dengan dan tanpa riwayat keluarga penyakit kardiovaskular berdasarkan usia.

\begin{tabular}{ccccc}
\hline Usia & \multicolumn{2}{c}{ RPK (+) } & \multicolumn{2}{c}{ RPK (-) } \\
\cline { 2 - 5 } (tahun) & Jumlah & \% & Jumlah & \% \\
\hline $26-30$ & 2 & 9 & 5 & 23 \\
$31-35$ & 5 & 23 & 5 & 23 \\
$36-40$ & 4 & 18 & 4 & 18 \\
$41-45$ & 5 & 23 & 2 & 9 \\
$46-50$ & 6 & 27 & 6 & 27 \\
TOTAL & 22 & 10 & 22 & 10 \\
\hline
\end{tabular}




\section{Indeks massa tubuh (IMT)}

Subjek penelitian dengan IMT 25,00$29,99 \mathrm{~kg} / \mathrm{m}^{2}$ diklasifikasikan obes I dan IMT $\geq 30,00 \mathrm{~kg} / \mathrm{m}^{2}$ diklasifikasikan obes II. Subjek penelitian RPK (+) memiliki nilai rata-rata IMT $29,01 \mathrm{~kg} / \mathrm{m}^{2}$ dengan standar deviasi 4,02843, sedangkan yang RPK (-) mempunyai nilai rata-rata IMT $29,38 \mathrm{~kg} / \mathrm{m}^{2}$ dengan standar deviasi 2,68730 (Tabel 3).

Tabel 3. Deskripsi IMT subjek penelitian dengan dan tanpa riwayat keluarga penyakit kardiovaskular.

\begin{tabular}{ccccc}
\hline IMT & Mean & $\begin{array}{c}\text { Standar } \\
\text { deviasi }\end{array}$ & $\begin{array}{c}\text { Nilai } \\
\text { maks. }\end{array}$ & $\begin{array}{c}\text { Nilai } \\
\text { min. }\end{array}$ \\
\hline RPK (+) & 29,01 & 4,02843 & 42,20 & 25,40 \\
RPK (-) & 29,38 & 2,68730 & 35,50 & 25,20 \\
\hline
\end{tabular}

\section{Lingkar perut (LP)}

Deskripsi lingkar perut (LP) subjek penelitian dengan RPK (+)memperlihatkan nilai rata-rata LP 92,04 cm dengan standar deviasi 7,87689, sedangkan subjek penelitian dengan RPK (-) memperlihatkan nilai rata-rata $\mathrm{LP}$ 93,54 $\mathrm{cm}$ dengan standar deviasi 6,07671 (Tabel 4).

Tabel 4. Deskripsi lingkar perut subjek penelitian dengan dan tanpa riwayat keluarga penyakit kardiovaskular.

\begin{tabular}{ccccc}
\hline LP & Mean & $\begin{array}{c}\text { Standar } \\
\text { deviasi }\end{array}$ & $\begin{array}{c}\text { Nilai Nilai min. } \\
\text { maks. }\end{array}$ \\
\hline RPK (+) & 92,04 & 7,87689 & 113 & 84 \\
RPK (-) & 93,54 & 6,07671 & 101 & 82 \\
\hline
\end{tabular}

\section{Hasil pemeriksaan kadar gula darah post-prandial}

Rata-rata kadar gula darah dua jam post-prandial subjek penelitian RPK (+) sebesar 137,18 mg/dL dengan standar deviasi 74,688, sedangkan pada subjek penelitian RPK (-) sebesar 114,55 mg/dL dengan standar deviasi 48,797 (Tabel 5).
Tabel 5. Deskripsi kadar gula darah postprandial subjek penelitian dengan dan tanpa riwayat keluarga penyakit kardiovaskular.

\begin{tabular}{ccccc}
\hline GD2PP & Mean & $\begin{array}{c}\text { Standar } \\
\text { deviasi }\end{array}$ & $\begin{array}{c}\text { Nilai } \\
\text { maks. }\end{array}$ & $\begin{array}{c}\text { Nilai } \\
\text { min. }\end{array}$ \\
\hline RPK(+) & 137,18 & 74,688 & 376 & 75 \\
RPK(-) & 114,55 & 48,797 & 301 & 71 \\
\hline
\end{tabular}

\section{Usia dan kadar gula darah}

Dari hasil uji statistik, subjek penelitian RPK (+) menunjukkan bahwa tidak terdapat hubungan bermakna antara usia dan kadar gula darah post-prandial $(P$ $>0,05)$. Demikian pula subjek penelitian RPK (-) menunjukkan bahwa tidak terdapat hubungan bermakna antara usia dan kadar gula darah dua jam post-prandial $(P$ $>0,05)$.

Tabel 6. Hubungan usia dengan kadar gula darah post-prandial.

\begin{tabular}{ccc}
\hline & \multicolumn{2}{c}{ Subjek penelitian } \\
\cline { 2 - 3 } & RPK (+) & RPK (-) \\
\cline { 2 - 3 } Chi square & GD2PP & GD2PP \\
& 0,746 & 0,800 \\
\hline
\end{tabular}

\section{IMT dan kadar gula darah}

Hasil uji statistik pada subjek penelitian RPK (+) dan RPK (-) menunjukkan bahwa tidak terdapat hubungan bermakna antara IMT dan kadar gula darah dua jam postprandial $(P>0,05)$ (Tabel 7).

Tabel 7. Hubungan IMT dengan kadar gula darah post-prandial.

\begin{tabular}{ccc}
\hline & \multicolumn{2}{c}{ Subjek penelitian } \\
\cline { 2 - 3 } & RPK $(+)$ & RPK $(-)$ \\
\cline { 2 - 3 } chi square & GD2PP & GD2PP \\
& 0,131 & 0,534 \\
\hline
\end{tabular}

\section{Riwayat keluarga penyakit kardiovaskular dan kadar gula darah post-prandial}

Berdasarkan hasil uji statistik diperoleh 
nilai $P=0,680(P>0,05)$ yang berarti tidak terdapat hubungan antara riwayat keluarga penyakit kardiovaskular dan kadar gula darah post-prandial (Tabel 8).

Tabel 8. Hubungan riwayat keluarga penyakit kardiovaskular dengan kadar gula darah postprandial.

\begin{tabular}{cc}
\hline & $\begin{array}{c}\text { Riwayat keluarga penyakit } \\
\text { kardiovaskular }\end{array}$ \\
\cline { 2 - 2 } Chi square & GD2PP \\
& 0,680 \\
\hline
\end{tabular}

Hasil analisis kadar gula darah dua jam post-prandial memperlihatkan nilai $P$ $=0,209(P>0,05)$, yang berarti tidak terdapat perbedaan bermakna antara kadar gula darah 2 jam post-prandial pada subjek penelitian dengan dan tanpa riwayat penyakit kardiovaskular (Tabel 9).

Tabel 9. Perbandingan kadar gula darah postprandial subjek penelitian dengan dan tanpa riwayat keluarga penyakit kardiovaskular.

\begin{tabular}{cc}
\hline & $P$ \\
\hline GD2jamPP & 0,209 \\
\hline
\end{tabular}

\section{BAHASAN}

Penelitian yang dilakukan Depkes RI tahun 2010 mengemukakan bahwa jumlah pria dan wanita cenderung lebih tinggi untuk yang kelebihan berat badan dibanding yang kurus. Dalam penelitian tersebut dinyatakan bahwa obesitas mencapai puncak pada kelompok usia 4049 tahun dengan kejadian obesitas pada pria $21,4 \%$ dan wanita $43,7 \% .^{5}$ Usia merupakan faktor risiko yang tidak dapat diubah terhadap kejadian obesitas. Kantachuvessiri et al. ${ }^{12}$ menyatakan bahwa kecenderung obesitas lebih tinggi pada usia 40-59 tahun dibanding dengan usia $\leq 40$ tahun; hal ini diduga karena aktivitas fisik yang kurang, melambatnya metabolism, dan frekuensi mengonsumsi pangan yang meningkat. Rodiana ${ }^{13}$ dari Universitas Pembangunan Nasional menyatakan bahwa tidak terdapat perbedaan bermakna antara subjek penelitian yang berusia 45-60 tahun dan $\geq 60$ tahun terhadap perubahan kadar gula darah. ${ }^{13}$ Rahmawati et al. $^{14}$ di Universitas Indonesia Depok mengemukakan bahwa tidak terdapat pengaruh usia terhadap kejadian hiperglikemia $(P>0,05)$.

Pada penelitian ini terdapat sebanyak 44 orang wanita obes sentral dengan persentase tertinggi pada kelompok usia 41-50 tahun (43\%); hal ini sesuai dengan penelitian Depkes RI 2010 dan penelitian Kantachuvessiri et al. ${ }^{5,12}$ Penelitian ini juga menunjukkan tidak terdapat hubungan antara usia dan kadar gula darah pada subjek penelitian dengan dan tanpa riwayat keluarga penyakit kardiovaskular.

Proses penuaan berhubungan dengan perubahan metabolisme glukosa. Proses penuaan memengaruhi sel beta pankreas yang berakibat terhadap menurunnya sintesis dan sekresi insulin. Menurut Anderson dalam Modern Nutrition in Health and Disease (2006), efisiensi metabolisme glukosa akan berkurang pada dekade ketiga atau keempat dalam kehidupan dan akan terjadi kemunduran yang cepat pada usia 60 tahun. Perubahan toleransi glukosa juga dipengaruhi oleh faktor-faktor lain seperti resistensi insulin, defisiensi sel beta dan obesitas dapat memperbesar timbulnya gejala diabetes. ${ }^{14}$

Individu dengan obesitas sentral berisiko tinggi untuk hiperinsulinemia dan resistensi insulin yang menyebabkan berkembangnya DMT2 dan penyakit kardiovaskular. Peningkatan lingkar perut dapat menjadi penilai adanya gangguan sistemik pada regulasi penyimpanan energy. Akumulasi lemak viseral diperkirakan berperan penting terhadap etiologi DM tipe 2 melalui asam lemak bebas dan glukosa darah untuk dimetabolisme di sel-sel yang berespon terhadap insulin dan menstimulasi produksi glukosa endogen yang menyebabkan resistensi insulin serta hiperinsulinemia. Hal ini merupakan dekade awal bagi subjek DM tipe $2 .{ }^{15}$ 
Penelitian Sinaga $^{16}$ di Universitas Diponegoro Semarang mengemukakan bahwa uji statistik menunjukkan terdapat korelasi yang kuat antara aktifitas fisik dan perubahan IMT dengan peningkatan kadar gula darah puasa. ${ }^{16}$ Penelitian Sari ${ }^{17}$ di Universitas Diponegoro Semarang menyatakan bahwa wanita dengan IMT $\geq 30,0$ $\mathrm{kg} / \mathrm{m}^{2}$ mempunyai risiko lebih besar 3,75 kali terjadinya DM tipe 2 dibandingkan dengan IMT 25,0-29,0 kg/m². Bertambahnya IMT dan lingkar perut berisiko terhadap peningkatan kadar gula darah. ${ }^{17}$ Berbeda dengan yang dinyatakan Sari, Sulistianingrum, ${ }^{18}$ di Universitas Sebelas Maret Surakarta mengemukakan bahwa tidak terdapat hubungan bermakna antara IMT dan kadar gula darah puasa. ${ }^{18}$

Penelitian ini tidak menunjukkan hubungan bermakna antara IMT dengan kadar gula darah puasa dan postprandial. Klasifikasi obes II memiliki risiko 0,5 kali lebih besar untuk mengalami peningkatan kadar gula darah postprandial jika dibandingkan dengan obes I.

Sindroma metabolik (metabolic syndrome, MetS) ditandai dengan pengelompokan faktor risiko kardiovaskular. Dengan adanya diabetes, risiko penyakit kardiovaskular akan lebih meningkat. Dua faktor utama patogenesis dari MetS ialah tubuh kelebihan lemak (obesitas) dan kerentanan metabolik. ${ }^{19,20}$ WHO, National Cholesterol Education Program's Adult Treatment Panel III (NCEP: ATP III), European Group for the Study of Insulin Resistance (EGIR), dan International Diabetes Federation (IDF) mendefinisikan MetS sebagai faktor risiko yang meliputi toleransi glukosa terganggu, glukosa puasa terganggu atau resistensi insulin, dislipidemia, obesitas sentral, dan hipertensi. Sebagai faktor risiko penyakit kardiovaskular, MetS juga berhubungan dengan DM tipe 2 (toleransi glukosa terganggu dan glukosa puasa terganggu). DM tipe 2, Familial Combined Hyperlipidemia (FCHL), dan MetS menunjukkan bahwa faktor genetik yang sama dapat berkontribusi pada keadaan patologis berbeda. $^{20}$ Riwayat keluarga merupakan salah satu faktor risiko yang tidak dapat diubah. ${ }^{21}$ Nasution, ${ }^{22}$ melaporkan dalam penelitiannya bahwa belum terlihat perubahan metabolik pada anak dalam usia 19-29 tahun. Kadar gula darah postprandial lebih tinggi pada anak dengan riwayat normotensi dalam keluarga daripada anak dengan riwayat hipertensi esensial dalam keluarga namun masih dalam batas normal. ${ }^{22}$ Gupta et al. ${ }^{21}$ melaporkan bahwa kadar gula darah >126 $\mathrm{mg} / \mathrm{dL}$ dianggap sebagai salah satu faktor utama terjadinya PJK. Terdapat hubungan yang bermakna antara riwayat keluarga dengan risiko terjadinya sindrom metabolik pada pria dan wanita.

Berbeda dengan hasil penelitian sebelumnya, penelitian ini tidak memperlihatkan adanya hubungan bermakna antara riwayat penyakit kardiovaskular dalam keluarga dengan kadar gula darah puasa dan postprandial. Hasil uji statistik menunjukkan risiko terjadinya peningkatan kadar gula darah postprandial 1,1 kali lebih tinggi pada wanita obes sental tanpa riwayat keluarga penyakit kardiovaskular $(P=1,198)$ daripada wanita obes sentral dengan riwayat keluarga penyakit kardiovaskular $(P=0,851)$.

Perbedaan hasil penelitian ini kemungkinan karena jumlah sampel yang minimal. Penelitian ini menggunakan desain cross sectional sehingga seharusnya dibutuhkan sampel yang cukup banyak. Selain keterbatasan waktu, adanya kriteria inklusi serta ekslusi memperkecil jumlah sampel yang memenuhi kriteria. Selain itu, terjadinya peningkatan kadar gula darah umumnya pada usia >45 tahun, sehingga usia dan klasifikasi obes juga dapat memengaruhi hasil penelitian ini. Usia subjek penelitian ini terbanyak <45 tahun dan klasifikasi obes I lebih tinggi dibandingkan obes II pada subjek penelitian dengan riwayat keluarga penyakit kardiovaskular. Sebaliknya pada subjek penelitian tanpa riwayat keluarga penyakit kardiovaskular, klasifikasi obes II lebih tinggi dibandingkan obes I.

\section{SIMPULAN}

Dari hasil penelitian ini dapat disim- 
pulkan bahwa tidak terdapat perbedaan bermakna antara kadar gula darah postprandial pada wanita obes sentral dengan dan tanpa riwayat keluarga penyakit kardiovaskular.

\section{DAFTAR PUSTAKA}

1. Sugondo S. Obesitas. In: Sudoyo AW, Setiyohadi B, Alwi I, Simadibrata M, Setiati S, editors. Buku Ajar Ilmu Penyakit Dalam. Jakarta: Interna Publishing, 2009; p. 1973-83.

2. Chan RSM, Woo J. Prevention of overweight and obesity: how effective is the current public health approach. Int $\mathrm{J}$ Environ Res Public Health. 2010;7:765-83.

3. World Health Organization. Obesity: preventing and managing the global epidemic [homepage on the internet]. c2000 [update 2004; cited 2012 Oct 16]. Available from : http://whqlibdoc.who.int/trs/WHO_TR S_894.pdf

4. Justitia NL. Hubungan obesitas dengan peningkatan kadar gula darah pada guru-guru SMP negeri 3 Medan [Skripsi]. Medan: Universitas Sumatera Utara; 2012.

5. Kementrian Kesehatan RI. Riset kesehatan dasar. 2010 [cited 2012 Oct 25]. Available from: http://www.riskesdas. litbang.depkes.go.id/download/TabelRi skesdas2010.pdf

6. Marfianti E. Perbedaan kadar resistin pada obes dengan resistensi insulin dan obes tanpa resistensi insulin. JKKI [serial on the internet]. 2006 [cited 2012 Sept 26]. Available from: http://journal.uii.ac.id/index.php/JKKI/ article/viewFile/546/470.

7. Husni A. Perbandingan kadar gula darah pada mahasiswa FK-USU stambuk 2007-2010 yang obesitas rutin berolahraga dengan tidak rutin berolahraga selama 30 menit berolahraga [Skripsi]. Medan: Universitas Sumatera Utara; 2010.

8. Zheng-zhong JI, Zhe DAI, Yan-cheng XU. A new tumor necrosis factor (TNF)- $\alpha$ regulator, lipopolysaccharides-induced TNF- $\alpha$ factor, is associated with obesity and insulin resistance. Chin Med J. 2011;124(2):177-82.
9. Manaf A. Insulin: mekanisme sekresi dan aspek metabolism. In: Sudoyo AW, Setiyohadi B, Alwi I, Simadibrata M, Setiati S, editors. Buku Ajar Ilmu Penyakit Dalam. Jakarta: Interna Publishing, 2009; p.1896-9.

10. Chaudhary R, Likidlilid A, Peerapatdit T, Tresukosol D, Srisuma S, Ratanamaneechat S, et al. Apolipoprotein E gene polymorphism: effects on plasma lipids and risk of type 2 diabetes and coronary artery disease. Cardiovascular Diabetology. 2012;11 (36):1-11.

11. Zeljko HM, Skaric-Juric T, Narancic NS, Tomas Z, Baresic A, Salihovic MP, et al. E2 allele of the apolipoprotein E gene polymorphism is predictive for obesity status in Roma minority population of Croatia. Lipids Health Dis. 2011;10:9.

12. Kantachuvessiri A, Sirivichayakul C, KaewKungwal J, Tungtrongchitr R, Lotrakul M. Factors associated with obesity among workers in a metropolitan waterworks authority. Southeast Asian J Trop Med Public Health. 2005;36(4):1057-65.

13. Rodiana M. Pengaruh senam diabetes terhadap perubahan kadar gula darah pada pasien diabetes melitus tipe 2 di Persadia Hospital Cinere Depok tahun 2011[Skripsi]. Jogyakarta: Universitas Pembangunan Nasional; 2011.

14. Rahmawati, Setiarini A, Sudikno. Pengaruh status gizi terhadap kejadian hiperglikemi pada pegawai negeri sipil: studi kasus di kota Depok tahun 2009. Gizi Indon. 2009;32(2):163-77.

15. Yuliasih W. Obesitas abdominal sebagai faktor risiko peningkatan kadar glukosa darah [Artikel penelitian]. Semarang: Universitas Diponegoro; 2009.

16. Sinaga E. Pengaruh pemberian susu kedelai terhadap kadar glukosa darah puasa pada wanita prediabetes. Journal of Nutrition College. 2012;1(1):563-79.

17. Sari R. Beberapa faktor risiko kadar glukosa darah pada pasien obesitas di instalasi rawat jalan RSUP DR. Kariadi Semarang [Artikel penelitian]. Semarang: Universitas Diponegoro; 2010.

18. Sulistianingrum ND. Hubungan indeks massa tubuh dan rasio lingkar pinggang 
pinggul dengan kadar gula darah puasa [Skripsi]. Surakarta: Universitas Sebelas Maret; 2010.

19. Grundy SM. Metabolic Syndrome: A Multiplex Cardiovascular Risk Factor. J Clin Endocrinol Metab. 2007;92:399404.

20. Kristiansson K. Genetics of cardiovascular disease: A candidate gene study of USF1. Helsinki: National Public Health Institute; 2008.

21. Gupta R, Sarna M, Rastogi $P$, Bhagat $N$, Gupta VP. Family history of coronary heart disease and prevalence of risk factor in a population-based cohort: Jaipur heart watch-3. South Asian Journal of Preventive Cardiology [homepage on the Internet]. Nodate [cited 2013 Aug 07]. Available from: http://sajprevcardiology.com/vol9/vol9 _1/familyhistoryofcoronary.htm.

22. Nasution SR. Gambaran metabolik glukosa, lipid dan insulin pada keturunan hipertensi esensial yang normotensi. Medan: USU repository; 2005 [cited 2012 Oct 18]. Available from: usu.ac.id. 